\title{
Efficacy of gefitinib and radiotherapy combination in Indonesian patients with lung adenocarcinoma
}

\author{
ELISNA SYAHRUDDIN ${ }^{1, *}$, AIDA LUFTI HUSWATUN ${ }^{2, *}$, ARI PRABOWO ${ }^{1, *}$, JAMAL ZAINI $^{1}$, \\ FARIZ NURWIDYA $^{1, *}$, ACHMAD HUDOYO ${ }^{1}$, ANWAR JUSUF ${ }^{1}$ \\ ${ }^{1}$ Department of Pulmonology and Respiratory Medicine, Faculty of Medicine Universitas Indonesia, Persahabatan National \\ Respiratory Referral Hospital, Jalan Persahabatan Raya No. 1, Rawamangun, Jakarta, Indonesia \\ ${ }^{2}$ Department of Radiotherapy, Persahabatan National Respiratory Referral Hospital, Jalan Persahabatan Raya No. 1, \\ Rawamangun, Jakarta, Indonesia
}

\begin{abstract}
Introduction. Combinations of gefitinib and radiotherapy have been observed to have synergistic and anti-proliferative effects on lung cancer in vitro. In the clinical setting, patients who presented with respiratory difficulties such as superior vena cava syndrome (SVCS), radiotherapy should be given immediately to address the emergency while waiting for the results of epidermal growth factor receptor (EGFR) mutation test. However, there has been no study that described the role of radiotherapy in Indonesian patients with EGFR-mutant lung adenocarcinoma.

Methods. This preliminary study aimed to evaluate the efficacy and toxicities of gefitinib and radiotherapy combination in lung adenocarcinoma patients in Persahabatan National Respiratory Referral Hospital, Jakarta, Indonesia. Subjects were consecutively recruited between January 2013 and December 2016.

Results. Thirty-one lung adenocarcinoma with EGFR mutations were enrolled. Most of them were male $(51.61 \%)$ with a median age of 54.5 years old (range $38-70$ years old). EGFR mutation characteristics were on exon $21 \mathrm{~L} 858 \mathrm{R}$ point mutation (61.30\%), exon 21 L861Q point mutation (16.12\%) and exon 19 deletion (22.58\%). Radiotherapy was given at doses between 30-60 Gy. Among these subjects, median progression-free survival (PFS) was 185 days $(95 \% \mathrm{CI} ; 123.69-246.30)$, 1 -year survival rate (1-yr) was $45.2 \%$, and median overall survival (OS) was 300 days $(95 \% \mathrm{CI}$; 130.94 - 469.06). There were no grade $3 / 4$ hematological and nonhematological toxicities recorded. The most frequent grade 1 and 2 non-hematological toxicities were skin rash, diarrhea, and paronychia that might be related to tyrosine kinase inhibitor (TKI).

Conclusion. The combination of TKI with radiation may be considered in EGFR-mutant lung adenocarcinoma subjects.
\end{abstract}

Key words: Lung, adenocarcinoma, molecular targeted therapy, radiation therapy, treatment efficacy.

\section{INTRODUCTION}

Primary lung cancer is a malignant disease originated from the bronchial epithelial cell $[1,2]$. Globally, lung cancer is a major newly diagnosed cancer disease, comprising $12.4 \%$, and responsible for $17.6 \%$ of cancer-related mortality [3]. Data from the Department of Anatomical Pathology of the Persahabatan Hospital, Jakarta, Indonesia, showed that lung cancer prevalence was more than $50 \%$ of all diagnosed cancer. Report from Dharmais Indonesian Cancer Hospital, Jakarta, Indonesia, from the years 2003-2007 showed that tracheal, bronchus and lung cancer were the second most prevalent malignancy-related morbidity in male (13.4\%) after nasopharyngeal cancer $(13.63 \%)$ and were the most common-related mortality in male $(28.94 \%)$ [1, 2]. This disease was also becoming more prevalent in Asian population $[4,5]$.

In July 2002, gefitinib as an epidermal growth factor receptor-tyrosine kinase inhibitor (EGFR-TKI) has been approved in the treatment of non-small cell lung cancer (NSCLC) in Japan [6]. Pre-clinical data suggest that blockade of EGFR signaling pathway will enhance the radiation-induced cytotoxic effect [7]. It has been reported that the combination of gefitinib and radiotherapy resulted in synergistic anti-proliferative effect against NSCLC cells in vitro [8]. However, there has been no report about the efficacy and toxicity of radiotherapy in Indonesian EGFR-mutant lung cancer patients. The purpose of this study is to address the efficacy and toxicities, 
both hematologic and non-hematologic, of combining gefitinib and radiotherapy in lung adenocarcinoma patients with EGFR sensitizing-mutation.

\section{MATERIALS AND METHODS}

This is an analytical and observational retrospective cohort based on patient medical records who meet the inclusion criteria. The inclusion criteria were lung adenocarcinoma patients with sensitizing EGFR mutation, who received gefitinib minimally 2 months and were treated with radiotherapy as minimal as $30 \mathrm{~Gy}$ in the primary tumor. In a sequential manner, the radiotherapy was given 1 month after progressive disease during gefitinib treatment. The exclusion criterion was subject who was unable to be traced after diagnosis has been established. This study was conducted at the Persahabatan Hospital, Jakarta, Indonesia, from May 2016 till March 2017 and has been granted ethical clearance by the Institutional Board Review (IRB) of the Faculty of Medicine Universitas Indonesia (No. 435/UN2.FI/ETIK/2-16) and Persahabatan Hospital (No. 124/KEPK-RSUPP/08/2016). EGFR mutation analysis was performed by using Polymerase chain reaction-based High resolution Melting (PCR-HRM). Therapeutic response was assessed based on the Response Evaluation Criteria in Solid Tumors (RECIST) that combine subjective, semiobjective and objective assessment.

Statistical analysis was performed on parametric and non-parametric data. The parametric test was performed on data that presented as interval scale, ratio and normally distributed, meanwhile non-parametric test was employed in nominal and ordinal data or was not normally distributed. The statistical testing was done by Chi-square test. Survival curves were generated by Kaplan-Meier technique. Significant association was established with $P$-value below 0.05 . SPSS version 20 (IBM Corp, Armonk, NY, USA) was used in the statistical analysis.

\section{RESULTS}

Initially, there were totally 1359 patients who received radiotherapy in the Persahabatan Hospital, Jakarta, Indonesia, from January 2013 until December
2016 and 593 subjects were lung cancer patients. The number of lung adenocarcinoma patients who received targeted therapy combined with radiotherapy was 31 subjects. Seventeen (58.1\%) patients received $30 \mathrm{~Gy}, 9(25.8 \%)$ patients received $40 \mathrm{~Gy}$, and $5(16.1 \%)$ patients received $50 \mathrm{~Gy}$. Additional radiotherapy was given in a concurrent manner in 26 subjects $(83.9 \%)$, sequential manner in 5 subjects $(16.1 \%)$ and there was no alternating manner. Subject gender was equally distributed between male and female and most of these subjects were non-smokers. The median age was 56 years old, with male slightly younger than female. Most of the male subjects were on performance status 2, while most of the female subjects were on performance status 1 . The majority of the studied patients were on Stage 4B, the most common complication for male and female were SVCS and clinically progressive disease, respectively. The 'other' clinical condition for radiotherapy includes patients who, while waiting for the EGFR mutational analysis results, had a subjective symptom of chest pain. The most common EGFR mutation was Exon 21 L858R. The subject characteristics are described in Table 1.

First, we analyzed the association between therapeutic response and the type of mutation. As described in Table 2, there was a tendency that patients with Exon 19 deletion have more favorable outcome compared to other type of mutations, although it did not reach a statistically significant threshold $(P=0.07)$.

We postulated that patients with superior vena cava syndrome (SVCS) would have the benefit from radiotherapy as this would abate the immediate threat. We then compared the clinical response between SVCS subjects and those with other conditions. As shown in Table 3, SVCS patients had a quite similar total clinical response (sum of complete response, partial response, and stable disease) compared to non-SVCS patients $(81.8 \%$ vs. $80 \%$, respectively).

Next, we analyzed the association between therapeutic response and the time of radiotherapy. In Table 4, both concurrent and sequential radiotherapy resulted in partial response and/or stable disease in half of the subjects and there was no significant association between clinical response and the time of radiotherapy. 
Table 1

Demographic characteristic of EGFR-mutant lung adenocarcinoma patients who received combination of gefitinib and radiotherapy $(n=31)$

\begin{tabular}{|c|c|c|c|c|c|c|}
\hline & \multicolumn{2}{|c|}{ Male } & \multicolumn{2}{|c|}{ Female } & \multicolumn{2}{|c|}{ Total } \\
\hline & $\mathbf{N}$ & $\%$ & $\mathbf{N}$ & $\%$ & $\mathbf{N}$ & $\%$ \\
\hline Number of patients & 16 & $51.6 \%$ & 15 & $49.4 \%$ & 31 & $100 \%$ \\
\hline \multicolumn{7}{|l|}{ Age } \\
\hline Range & $54.5(38-70)$ & & $57(38-77)$ & & $56(38-77)$ & \\
\hline Mean & 52.16 & & 57.60 & & 57.60 & \\
\hline \multicolumn{7}{|l|}{ Smoking status } \\
\hline Yes & 4 & 25.0 & 0 & 0 & 4 & 12.9 \\
\hline No & 12 & 75.0 & 15 & 100 & 27 & 87.1 \\
\hline \multicolumn{7}{|l|}{ Clinical performance } \\
\hline Performance status 0 & 0 & 0 & 0 & 0 & 0 & 0 \\
\hline Performance status 1 & 6 & 37.5 & 10 & 66.7 & 16 & 51.6 \\
\hline Performance status 2 & 10 & 62.5 & 5 & 33.3 & 15 & 48.4 \\
\hline Performance status 3 & 0 & 0 & 0 & 0 & 0 & 0 \\
\hline \multicolumn{7}{|l|}{ Stage } \\
\hline $3 \mathrm{~A}$ & 2 & 12.50 & 1 & 6.67 & 3 & 9.68 \\
\hline $3 \mathrm{~B}$ & 0 & 0 & 1 & 6.67 & 1 & 3.22 \\
\hline $4 \mathrm{~A}$ & 8 & 50 & 7 & 46.67 & 15 & 48.39 \\
\hline 4B & 6 & 37.5 & 6 & 40 & 12 & 38.71 \\
\hline \multicolumn{7}{|l|}{ Clinical condition } \\
\hline Superior vena cava syndrome & 9 & 29.05 & 2 & 6.45 & 11 & 35.5 \\
\hline Progressive & 2 & 6.45 & 5 & 16.10 & 7 & 22.6 \\
\hline Others & 5 & 16.10 & 8 & 25.80 & 13 & 41.9 \\
\hline \multicolumn{7}{|l|}{ EGFR mutation type } \\
\hline Exon 19 deletion & 3 & 18.75 & 4 & 26.67 & 7 & 22.58 \\
\hline Exon $21 \mathrm{~L} 861 \mathrm{Q}$ & 3 & 18.75 & 2 & 13.33 & 5 & 16.12 \\
\hline Exon $21 \mathrm{~L} 858 \mathrm{R}$ & 10 & 62.50 & 9 & 60 & 19 & 61.30 \\
\hline \multicolumn{7}{|l|}{ Therapeutic Response } \\
\hline Complete response & 0 & 0 & 0 & 0 & 0 & 0 \\
\hline Partial response & 3 & 9.7 & 3 & 9.7 & 6 & 19.4 \\
\hline Stable disease & 3 & 9.7 & 6 & 19.4 & 9 & 29 \\
\hline Progressive disease & 10 & 32.3 & 6 & 19.4 & 16 & 51.6 \\
\hline
\end{tabular}

Table 2

Association of clinical response and type of EGFR mutation in EGFR-mutant lung adenocarcinoma patient who received combination of gefitinib and radiotherapy

\begin{tabular}{|c|c|c|c|c|c|c|c|c|}
\hline \multirow[t]{3}{*}{ Response } & & & \multicolumn{4}{|c|}{ EGFR mutation type } & \multirow[t]{3}{*}{ Total } & \multirow[t]{3}{*}{$P$} \\
\hline & \multicolumn{2}{|c|}{ Exon 19 del } & \multicolumn{2}{|c|}{ Exon 21 L861Q } & \multicolumn{2}{|c|}{ Exon 21 L858R } & & \\
\hline & $\mathbf{N}$ & $\%$ & $\mathbf{N}$ & $\%$ & $\mathbf{N}$ & $\%$ & & \\
\hline Stable disease & 4 & $57.1 \%$ & 1 & $20 \%$ & 4 & $21 \%$ & 9 & 0.07 \\
\hline Partial response & 2 & $28.6 \%$ & 1 & $20 \%$ & 3 & $15.8 \%$ & 6 & \\
\hline Progressive disease & 1 & $14.3 \%$ & 3 & $60 \%$ & 12 & $63.2 \%$ & 16 & \\
\hline Total & 7 & $100 \%$ & 5 & $100 \%$ & 19 & $100 \%$ & 31 & \\
\hline
\end{tabular}

Kruskal-Wallis test

Table 3

Association of clinical response and superior vena cava syndrome as clinical conditions in EGFR-mutant lung adenocarcinoma patient who received combination of gefitinib and radiotherapy

\begin{tabular}{|c|c|c|c|c|c|c|}
\hline \multirow[t]{3}{*}{ Response } & \multicolumn{4}{|c|}{ Clinical conditions } & \multirow[t]{3}{*}{ Total } & \multirow[t]{3}{*}{$P$} \\
\hline & \multicolumn{2}{|c|}{ Superior vena cava syndrome (SVCS) } & \multicolumn{2}{|c|}{ Non-SVCS } & & \\
\hline & $\mathbf{N}$ & $\%$ & $\mathbf{N}$ & $\%$ & & \\
\hline Stable disease & 2 & $18.2 \%$ & 7 & $35.0 \%$ & 9 & 0.55 \\
\hline Partial response & 7 & $63.6 \%$ & 9 & $45.0 \%$ & 16 & \\
\hline Progressive disease & 2 & $18.2 \%$ & 4 & $20.0 \%$ & 6 & \\
\hline Total & 11 & $100 \%$ & 20 & $100 \%$ & 31 & \\
\hline
\end{tabular}

Chi-square test 
Table 4

Association of clinical response and radiotherapy time in EGFR-mutant lung adenocarcinoma patient who received combination of gefitinib and radiotherapy

\begin{tabular}{|c|c|c|c|c|c|c|}
\hline \multirow[t]{3}{*}{ Response } & \multicolumn{4}{|c|}{ Radiotherapy time } & \multirow[t]{3}{*}{ Total } & \multirow[t]{3}{*}{$P$} \\
\hline & \multicolumn{2}{|c|}{ Concurrent } & \multicolumn{2}{|c|}{ Sequential } & & \\
\hline & $\mathbf{N}$ & $\%$ & $\mathbf{N}$ & $\%$ & & \\
\hline Stable disease & 9 & $33.3 \%$ & 0 & $0 \%$ & 9 & 0.1683 \\
\hline Partial response & 4 & $14.8 \%$ & 2 & $50 \%$ & 6 & \\
\hline Progressive disease & 14 & $51.9 \%$ & 2 & $50 \%$ & 16 & \\
\hline Total & 27 & $100 \%$ & 4 & $100 \%$ & 31 & \\
\hline
\end{tabular}

Chi-square test

The median PFS and OS of all subjects in this study were 185 days (range 63 - 804 days, $95 \%$ CI 123.69 - 246.30) and 300 days (range $83-1174$ days, 95\%CI 130.94 - 469.06), respectively. As observed in Fig. 1A, median PFS for female was 286 days (range $91-804$ days, 95\% CI $0-600.04$ days), it was significantly better $(P=0.02)$ compared to male PFS of 145 days (range 63 - 748 days, 95\%CI $60.44-201.56$ days). In Fig. 1B, females also have the significantly longer OS $(P=0.04)$ compared to males; 547 days (range $161-1174$ days, $95 \%$ CI; 333.66 - 760.33) vs. 165 days (range $83-$ 1092 days, $95 \% \mathrm{CI} ; 94.44$ - 235.56).

We then analyzed the association of EGFR mutation type with the PFS (Fig. 2A) and OS (Fig. 2B). Exon 19 deletional mutation tended to have the longest PFS in this study: 347 days $(95 \% \mathrm{CI}$ : 100.64 - 593.36), followed by exon 21 L858R with PFS 205 days (95\%CI: 71.44 - 338.56) and exon
21 L861Q with PFS 123 days (95\%CI: $56.44-$ 189.56), although it was not statistically significant $(P=0.06)$. In terms of OS, the exon 19 deletion EGFR mutation had the longest OS 548 days $(95 \% \mathrm{CI}$; 481.28 - 614.72), followed by exon 21 L858R with OS 300 days (95\%CI; 159.23 - 440.77) and exon 21 L861Q point mutation with OS L861Q 185 days (95\%CI; $101.26-268.74)$.

As shown in Fig. 3A, subjects who received 30 Gy dose of radiotherapy had better $(P=0.05)$ PFS 140 days (95\%CI; 56.64 - 223.36), 40 Gy dose had PFS 163 days $(95 \% \mathrm{CI} ; 88.57$ - 237.48), 60 Gy dose had PFS 559 days $(95 \% \mathrm{CI} ; 0-1145.51)$. Moreover in Fig. 3B, subjects who received 30 Gy of radiotherapy had OS 224 days $(95 \% \mathrm{CI} ; 84.17$ $363.83)$, 40 Gy had OS 479 days (95\%CI; $373.82-$ $584.19)$ and 60 Gy had OS 650 days $(95 \% \mathrm{CI}$; 305.6 - 1401.4). In this study, there were $3(9.7 \%)$ patients who remained alive at the end of the study.
A

Survival (\%)

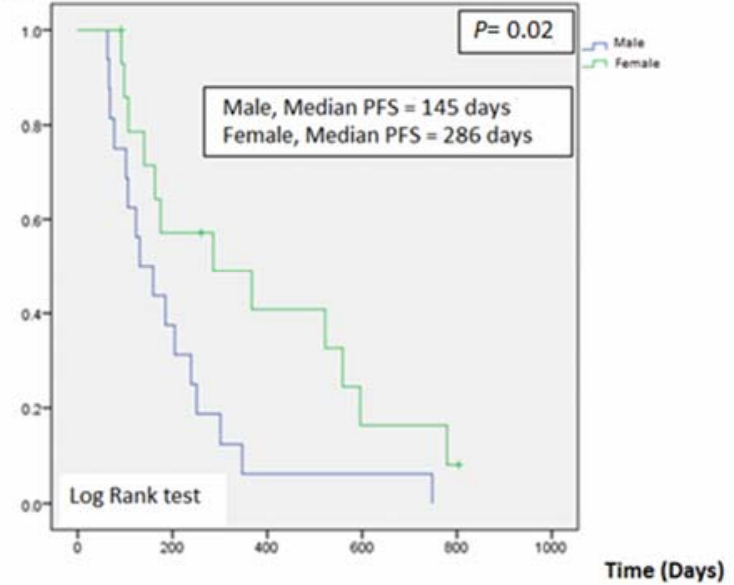

B

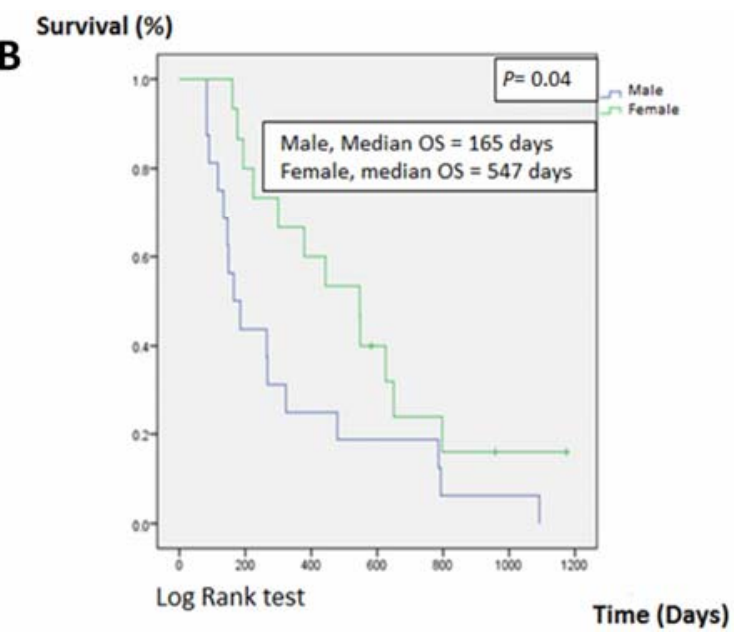

Figure 1. Kaplan-Meier curve of PFS (A) and OS (B) analysis based on gender among lung adenocarcinoma subjects who received combination of gefitinib and radiotherapy. 
A

Survival (\%)

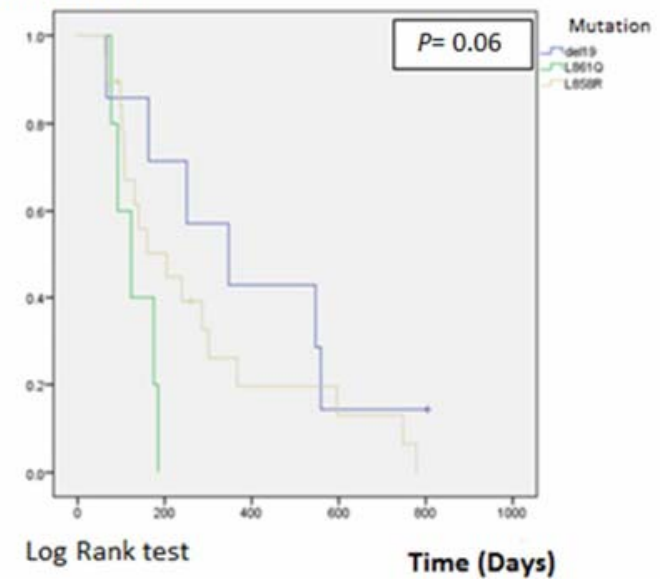

B Survival (\%)

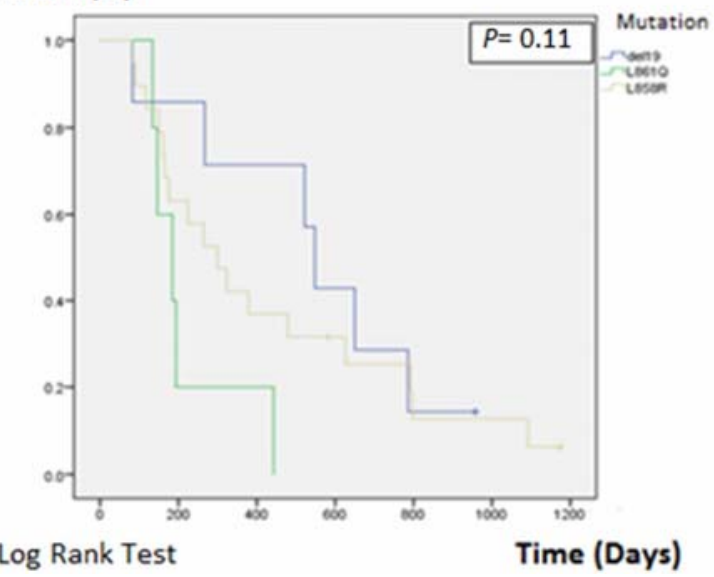

Figure 2. Kaplan-Meier curve of PFS (A) and OS (B) analysis based on EGFR mutation type among lung adenocarcinoma patients who received combination of gefitinib and radiotherapy.

A

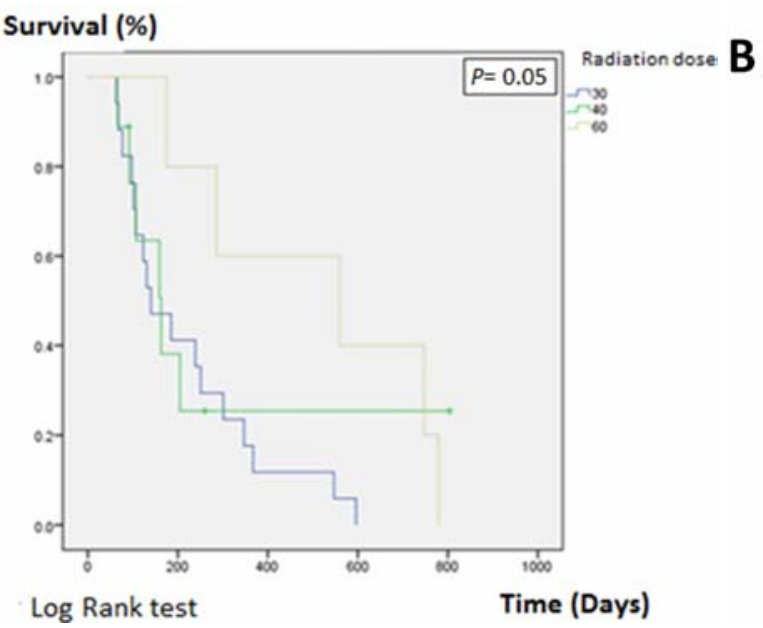

\section{Survival (\%)}

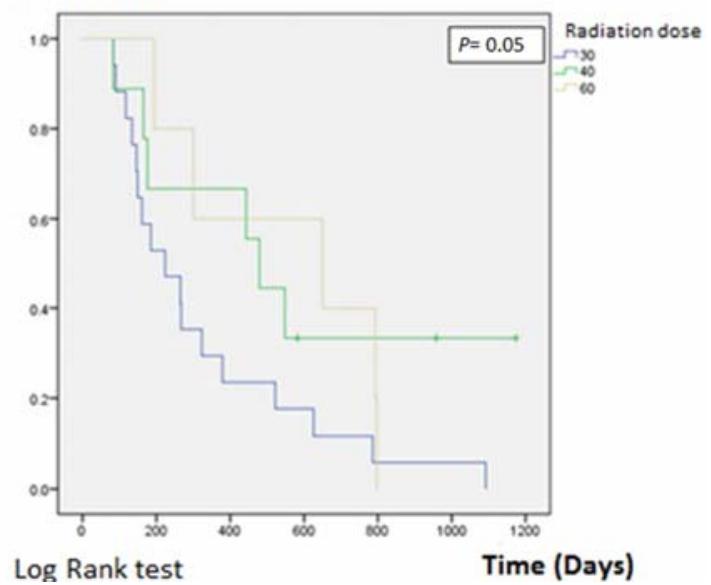

Figure 3. Kaplan-Meier curve of PFS (A) and OS (B) analysis based on radiotherapy dose among lung adenocarcinoma patients who received combination of gefitinib and radiotherapy. Note: Breslow Test.

The hematological and non-hematological toxicity among subjects who received a combination of gefitinib and radiotherapy are described in Table 5 and Table 6, respectively. Most of the male and female subjects had grade $1-2$ anemia, while 1 male subject had grade 3 - 4 leucopenia, another had grade $1-2$ thrombocytopenia, and a third presented with grade $3-4$ thrombocytopenia. In terms of non-hematological toxicities, there were some patients with grade $1-2$ skin rash, diarrhea, and paronychia.

Table 5

Hematological toxicities EGFR-mutant lung adenocarcinoma who received combination therapy

\begin{tabular}{lcccc}
\hline Hematological toxicities & Male & Female & Total & \% \\
\hline Anemia & 7 & & & \\
$\quad$ Grade 1-2 & 1 & 8 & 15 & 48.34 \\
$\quad$ Grade 3-4 & & 0 & & 3.22 \\
Leukopenia & 0 & 0 & 0 & 0 \\
$\quad$ Grade 1-2 & 1 & 0 & 1 & 3.22 \\
$\quad$ Grade 3-4 & & & 1 & 3.22 \\
Thrombocytopenia & 1 & 0 & 1 & 3.22 \\
$\quad$ Grade1-2 & 1 & 0 & \\
$\quad$ Grade 3-4 & & & \\
\hline
\end{tabular}


Table 6

Non-hematological toxicities of EGFR-mutant lung adenocarcinoma patients who received combination of gefitinib and radiotherapy

\begin{tabular}{lcccc}
\hline Non-hematological toxicities & Male & Female & Total & \% \\
\hline Skin rash & 5 & 3 & 8 & 25.8 \\
Grade 1-2 & 0 & 0 & 0 & 0 \\
Grade 3-4 & & & & \\
Diarrhea & 2 & 4 & 0 & 19.4 \\
$\quad$ Grade 1-2 & 0 & 0 & & 0 \\
Grade 3-4 & & & 3 & 9.7 \\
Paronychia & 2 & 1 & 0 & 0 \\
$\quad$ Grade 1-2 & 0 & 0 & & \\
Grade 3-4 & & & \\
\end{tabular}

\section{DISCUSSION}

The role of radiotherapy in the treatment of advanced NSCLC with sensitizing EGFR mutation is a major issue and still to be clarified. In a previous study involving inoperable NSCLC subjects, EGFRTKI had a better time-to-partial response than the radiotherapy in term of tumor shrinkage, meanwhile, the radiotherapy as an add-on therapy remains elusive [9]. This is the first study to elucidate the efficacy and toxicities of combining gefitinib and radiotherapy among Indonesian lung cancer patients with EGFR mutation. Demographic characteristic distribution of gender in both groups showed that there are nearly equal proportions of male and female. This is consistent with the previous study by Yahya et al. who reported EGFR-mutant non-squamous NSCLC were distributed between male $51.6 \%$ and female $49.4 \%$ [10]. The median age of subjects in the current study was 56 years old. However, a study by Chen et al. found the average of NSCLC patients in their study was 65 years old [11]. We observed that most of the studied subjects were Stage IV, followed by Stage IIIB and IIIA, meanwhile $\mathrm{Xu}$ et al. stated in their findings that patients with advanced stage disease of lung adenocarcinoma such as IIIB and IV have a chance of receiving benefit from concurrent radiotherapy and gefitinib [12]. The number of lung adenocarcinoma patients who smoke was smaller compared to those who reported not smoking ( $12.9 \%$ vs. $87.1 \%$, respectively). These results are in line with the PIONEER study which demonstrated that EGFR mutation in lung adenocarcinoma was prevalent in the Asian population, female and non-smokers [13].

There were 3 groups of clinical conditions who received the combination of gefitinib and radiotherapy: superior vena cava syndrome (SVCS); clinically progressive disease, and other conditions. In one report involving 81 SVKS patients hospitalized from 1983 to 1996, from 77 cancer-diagnosed cases, $76 \%$ among them were lung cancer cases [14]. Moreover, Mose et al. reported that among 35 SVCS patients, 20 patients were NSCLC, 12 patients were small cell lung cancer [15]. Radiation therapy combined with continuing EGFR-TKI led to a long PFS and OS in EGFR-mutant lung adenocarcinoma patients who suffered from local progression after initial response to EGFR-TKI $[16,17]$. However, the therapeutic role of radiotherapy alone in these populations remains to be addressed.

Based on RECIST criteria, among lung adenocarcinoma patients who received additional radiotherapy on EGFR-TKI treatment, $51.6 \%$ had progressive disease (PD), $29 \%$ had stable disease (SD) and no patients with complete response (CR). However, the total clinical response $(\mathrm{CR}+\mathrm{PR}+\mathrm{SD})$ in the study was good enough, nearly $50 \%$. A previous study by Levy et al. in lung adenocarcinoma patients treated with gefitinib 4 weeks after radiotherapy, in the RECIST assessment they found PD was 44\%, SD 38\% and PR19\% [18. A study by Chen et al. also observed that using RECIST criteria, the PD was the most common finding [11].

This study found good total clinical response for radiotherapy in lung adenocarcinoma patients with exon 19 deletional mutation followed by exon 21 mutation of L861Q and L858R. This result is consistent with a study conducted in China in which combination of radiotherapy and EGFR-TKI in EGFR-mutant NSCLC patients resulted longer overall survival in the group of exon 19 deletional mutation compared to exon 21 L858R mutation [19]. 
Progression-free survival (PFS) was determined from the day of starting treatment until progressive disease or patient died or during the last follow-up there was no PD, then it will be considered as PD and the study will be ended. In this study, the median PFS of all subjects was 185 days. Levy et al., in their phase 2 clinical trial, evaluated the efficacy of $250 \mathrm{mg}$ /day of gefitinib combined with thorax radiotherapy (66 Gy in 6.5 weeks, 2 Gy/day, 5 fraction/ week) followed by chemotherapy and vinorelbine as first-line treatment in patients with stage IIIB NSCLC non-selected based on EGFR mutation status [18]. They found the PFS was 5 months. Our mean PFS in this study was 265.65 days $( \pm 9)$ and this is similar with the study by Chen et al. who observed that the mean PFS was 9 months [11].

The median OS in this study was 300 days (range 83 - 1174 days). Another study of combining gefitinib and radiotherapy showed the median OS was 11 months and $31 \%$ of patients survived during the end of study [18]. Moreover, in a study involving a cohort of 28 lung adenocarcinoma patients, the OS was 8 months [11].

Side effects of combining radiotherapy and other modalities including molecular targeted therapy remain partially unresolved with several cases of high toxicity in the form of radiation pneumonitis which led to premature end of the study [20]. Toxicities that may occur from gefitinib treatment consist of hematologic (anemia, leukopenia, thrombocytopenia) and non-hematologic such as gastrointestinal disturbance (nausea, vomiting and diarrhea), skin problems (rash, itchy, acne and xerotic skin), alopecia, neuropathic disorder, paronychia, interstitial lung disease (ILD) and pain that have a degree according to WHO criteria $[2,6]$. We found skin rash, diarrhea and paronychia as non-hematologic toxicities, while anemia, leucopenia and thrombocytopenia as hematologic toxicities. A study by Kris et al. showed among NSCLC patients who received a combination of gefitinib $250 \mathrm{mg}$ and additional radiotherapy, $62 \%$ had a skin disorder and $57 \%$ had diarrhea as their non-hematologic toxicities [21]. Another study found that most frequent toxicities of the combination of radiotherapy and gefitinib were gastrointestinal disorder $81 \%$, itchy $81 \%$, respiration disorder $50 \%$ [18].

The main limitation of the current study was the nature of medical record-derived data as the cohort of retrospective observational analysis. Therefore, data relied on the completeness of the medical record. There were some incomplete data on the medical recorded during sampling.

\section{CONCLUSION}

To the best of our knowledge, this study is the first to report the efficacy and toxicities of combining radiotherapy and gefitinib in Indonesian patients with lung adenocarcinoma harboring sensitizing EGFR mutation. Combination of radiotherapy and gefitinib resulted in a favorable outcome in terms of PFS and OS with tolerable toxicities. Patients with exon 19 deletional mutation tended to have a better clinical response compared to other EGFR mutation type and the females were found to have better survival.

\footnotetext{
Acknowledgment. We would like to acknowledge Dr. Ahmad Utomo from Kalbe Genomics Corporation, Jakarta, Indonesia, for the EGFR mutation analysis.

* These authors contributed equally in this work.
}

Conflict of interest disclosure: The authors declare that there are not conflicts of interest

Sources of support: none

Abbreviations: EGFR, epidermal growth factor receptor; TKI, tyrosine kinase inhibitor; NSCLC, non-small cell lung cancer; PFS, progression-free survival; OS, overall survival; SVCS, superior vena cava syndrome.

Introducere. Combinația dintre gefitinib şi radioterapie s-a dovedit a avea efecte in vivo sinergice şi antiproliferative pe cancerul pulmonar. In contextul clinic al sindromului de venă cavă superioară (SVCS), radioterapia trebuie administrată imediat în urgență până când se obțin rezultatele mutației EGFR (receptorul factorului de creştere epidermic). Totuşi până acum nu a fost efectuat niciun studiu privind rolul radioterapiei la pacienții indonezieni $\mathrm{cu}$ cancer pulmonar şi mutație a EGFR.

Materiale şi metode. A fost realizat un studiu preliminar privind eficiența şi toxicitatea terapiei combinate geftinib şi radioterapie la pacienții din spitalul Persahabatan National Respiratory Referral Hospital, Jakarta, Indonesia. Pacienții au fost recrutați între ianuarie 2013 şi decembrie 2016. 
Rezultate. Au fost incluse în studiu 31 de cancere pulmonare cu mutații ale EGFR. Cei mai mulți pacienți erau de gen masculin (51.61\%) cu o vârstă medie de 54.5 ani (intervalul de vârstă fiind cuprins între 38 şi 70 de ani). Mutațiile EGFR au fost mutațiile punctiforme ale exonului 21 L858R (61.30\%), ale exonului 21 L861Q (16.12\%) şi deleția exonului 19 (22.58\%). Radioterapia a fost administrată in doze cuprinse între 30 și 60Gy. Printre acești pacienți supraviețuirea mediană (PFS) a fost de 185 zile (IC95\% 123.69-246.30), rata de supraviețire la 1 an a fost de $45.2 \%$ iar supraviețirea totală a fost de 300 zile (IC95\% 130.94-469.06). $\mathrm{Nu}$ au fost înregistrate toxicități nonhematologice sau hematologice de gradul 3/4. Cele mai frecvente toxicități nonhematologice de gradul 1/2 au fost rash cutanat, diaree şi paronichia toate fiind posibile datorită tratamentului cu inhibitori de tirozin-kinază (TKI).

Concluzii. Combinația dintre radioterapie şi TKI ar putea fi considerată la pacienții cu cancer pulomnar şi mutație EGFR.

Correspondence to: Fariz Nurwidya, MD, PhD, FAPSR, Department of Pulmonology and Respiratory Medicine, Universitas Indonesia Faculty of Medicine,

Persahabatan Hospital, Jalan Persahabatan Raya No.1, Rawamangun Jakarta 13230, Indonesia, Telephone: +62-21-489-3536. Fax: +62-21-489-0744

Email: fariz.nurwidya@gmail.com

\section{REFERENCES}

1. INDONESIAN NATIONAL COMMITTEE OF CANCER MANAGEMENT (Komite Nasional Penanggulangan Kanker [KPKN]). National Guideline of Lung Cancer Treatment (Panduan Nasional Penanganan Kanker Paru). Ministry of Health, the Republic of Indonesia (Kementrian Kesehatan Republik Indonesia); 2015.p.1-11.

2. JUSUF A., SYARIFUDDIN E., WIBAWANTO A., ICKSAN AG., JUNIARTI J., ENDARDJO S., et al. National Guideline for Diagnosis and Treatment of Non-Small Cell Lung Cancer in Indonesia (Pedoman diagnosis dan penatalaksanaan di Indonesia). The Indonesian Society of Respirology, Jakarta, 2016:1-31.

3. STOECKEL DA., MATUSCHAK GM., Lung Cancer. In: Human Organ System: Respiratory, an integrated approach to disease, McGraw-Hill, New York, 2003:307-318.

4. BRINK DS. Pathology of lung tumors, In: Human Organ System: Respiratory, an integrated approach to disease, McGrawHill, New York, 2003:295-305.

5. ISHII AS., KIM Y., SHIOZAWA T., IYAMA S., SATOMI K., KANO J., et al. Stratifin accelerates progression of lung adenocarcinoma at an early stage. Mol Cancer, 2015; 14:142.

6. CHANG SC., CHANG CY., SHIH JY., The role of epidermal growth factor receptor mutations and epidermal growth factor receptor-tyrosine kinase inhibitors in the treatment of lung cancer. Cancers. 2011; 3(2):2667-78.

7. RABEN D., Update of EGFR inhibitors and radiation in the management of non-small cell lung cancer, where do we go next? J Thorac Oncol., 2007; 2(8):153-4.

8. SATO Y., EBARA T., SUNAGA N., TAKAHASHI T., NAKANO T., Interaction of radiation and gefitinib on a human lung cancer cell line with mutant EGFR gene in vitro. Anticancer Res. 2012; 32(11):4877-4881.

9. IMAI H., SHUKUYA T., TAKAHASHI T, FUJIWARA S, MORI K, ONO A, AKAMATSU H, et al. Comparison of the timeto-response between radiotherapy and epidermal growth factor receptor - tyrosine kinase inhibitors for advanced non-small cell lung cancer with EGFR mutation. Anticancer Res. 2013; 33(8):3279-84.

10. YAHYA WS., ANDARINI SL., HUDOYO A., UTOMO AR., Efficacy and toxicities profile of the new epidermal growth factor receptor-tyrosine kinase (Profil efikasi dan toksisitas terapi target baru golongan epidermal growth factor receptor-Tyrosine kinase) [Thesis]. Jakarta: Universitas Indonesia; 2016.

11. CHEN J., FAN M., JIANG G., FU X., XIE L., XU X., et al., Phase I dose-escalation study of thoracic radiotherapy in combination with gefitinib in patients with IIIB/IV non-small cell lung cancer. Int J Radiat Oncol Biol Phys. 2010; 78(3):110-11.

12. XU Y., ZHANG Y., MA S., EGFR inhibitors with concurrent thoracic radiation therapy for locally advances non small cell lung cancer. Lung Cancer. 2011; 73(3):249-55.

13. SHI Y., AU JS., THONGPRASERT S., SRINIVASAN S., TSAI CM., KHOA MT., et al., A prospective, molecular epidemiology study of EGFR mutations in Asian patients with advanced non-small-cell lung cancer of adenocarcinoma histology (PIONEER). J Thorac Oncol., 2014 Feb; 9(2):154-62.

14. SYAHRUDDIN E., Sindrom vena kava superior. J Respirol Indones., 2009; 29(4):1-9.

15. MOSE S., STABIK C., EBERLEIN K, RAMM U., BOTTCHER HD., BUDISCHEWSKI K., Retrospective analysis of the superior vena cava syndrome in irradiated cancer patients. Anticancer Res., 2006; 26(6C):4933-6.

16. YU HA., SIMA CS., HUANG J., SOLOMON SB., RIMNER A., PAIK P., et al., Local therapy with continued EGFR tyrosine kinase inhibitor therapy as a treatment strategy in EGFR-mutant advanced lung cancers that have developed acquired resistance to EGFR tyrosine kinase inhibitors. J Thorac Oncol (2013) 8:346-51. 
17. CONFORTI F., CATANIA C., TOFFALORIO F., DUCA M., SPITALERI G., BARBERIS M., et al., EGFR tyrosine kinase inhibitors beyond focal progression obtain a prolonged disease control in patients with advanced adenocarcinoma of the lung. Lung Cancer, 2013; 81:440-4.

18. LEVY A., BARDET E., LACAS B., PIGNON JP., ADAM J., LACOROIX L., et al., A phase II open label multicenter study of gefitinib in combination with irradiation followed by chemotherapy in patients with in operable stage III non-small cell lung cancer. Oncotarget. 2017; 8(9):15924-33.

19. FAN Y., XU Y., GONG L., FANG L., LU H., QIN J., et al., Effects of icotinib with and without radiation therapy on patients with EGFR mutant non-small cell lung cancer and brain metastases. Sci Rep., 2017; 23(7):45193.

20. WAN J., COHEN V., AGULNIK J., FARIA S ., PORTELANCE L., OFIARA L., et al., Unexpected high lung toxicity from radiation pneumonitis in a Phase I/II trial of concurrent erlotinib with limited field radiation for intermediate prognosis patients with stage III or inoperable stage IIB non-small-cell lung cancer (NSCLC). Int J Radiat Oncol Biol Phys, 2009; $75(3)$ : S110.

21. KRIS MG., NATALE RB., HERBST RS., LYNCH TJ., PRAGER D., BELANI CP., et al., Efficacy of gefitinib, an inhibitor of the epidermal growth factor receptor tyrosine kinase in symptomatic patients with non-small cell lung cancer. JAMA 2003; 290(16):2149-58.

Received January 29, 2018 